○水川敦裕、石島 健、佐藤宏昭 （岩手医科大学耳鼻咽喉科）

I.はじめに

顔面神経鞘腫は繰り返し、そして緩徐に進行する顔面神経麻痺を特徴とし、その診断に 際して、Jackoson らは(1) 3 週間以上にわたる緩徐な神経麻痺、(2) 6 ヶ月以上経過しても回 復傾向の見られない麻瘏、(3)顔面けいれん（前駆症状)、(4)随伴する脳神経症状、(5)繰り返 す麻痺、(6)単一神経枝の麻痺、(7)疼痛 の 7 項目をあげている。

今回、我々は耳閉塞感を主訴に受診した顔面神経鞘腫と考えられる症例を経験したので 報告する。

II. 症例

55 歳 男性

主訴 : 耳閉塞感

既往歴 : 35 歳、50 歳で右顔面神経麻痺（共に他院にて治療、完治）

家族歴 : 特記事項なし

現病歴: 平成 15 年 2 月頃より右耳の耳閉塞感出現。同時期より右耳鳴（ジーン）も自覚 していた。しばらく様子をみるも改善を認めないため近医受診。鼓膜所見にて右桘骨短突 起の著しい突出を認め、通気にても改善を認めないため耳小骨奇形の疑いがあるとして、 当科紹介となった。難聴、自声強調、聴覚過敏、耳痛、眩暈は認めなかった。 経過：耳小骨奇形を疑い中耳ターゲットC Tを施行。耳小骨奇形は認めなかったが、顔 面神経第 1 膝部付近で上鼓室天蓋を破壊し、鼓室に突出する soft tissue density を認めた。 鑑別診断として顔面神経鞘腫、類表皮囊胞、脳へルニアなどが考えられるため、さらにM R I を施行した。MR I にて内耳道にT 1 で iso intensity signal、T 2 で high intensity signal のガドリニウムにて造影効果を示す mass を認め顔面神経鞘腫と考えられた。

検査所見 : 純音聴力検査にて初診時 (平成 15 年 7 月)、高音部閾値の上昇を認めた。平成 16 年 6 月には高音部聴力闇値の更なる聴力閾値の上昇を認め、低音部においても閾値上昇 を認めた。(図 1)

ENoG では眼輪筋、鼻筋、口輪筋のいずれも変化は認められていない。柳原法による顔面 神経麻痺スコアも変化はなかった。あぶみ骨筋反射は両側反応あり、左右差は認めなかっ た。

\title{
III. 考察
}

耳閉塞感は外耳、中耳、内耳、後迷路性疾患から上咽頭疾患、顎関節症に至るまで、そ の原因は多岐にわたる。しかし、本症例のように顔面神経鞘腫による耳閉塞感を主訴に受 診する例は、まれではないかと思われた。過去の文献においても顔面神経鞘腫の主訴は、 顔面神経麻痺、難聴がほとんどを占めている。

耳閉塞感は低音部における急性の感音難聴、すなおちメニエール病や低音障害型突発性 難聴などに多いが、中・高音域の急性感音難聴にもしばしばみられる。従って本症例の耳 閉塞感は、高音部聴カレベルの低下に伴う症状と思われる。他の機序としては顔面神経鞘 
腫発生により鼓室神経との交通枝が知覚異常感を生じ耳閉塞感として認知された可能性も 考えられた。

\section{IV.参考文献}

1. Jackson CG, Glasscock ME III, Hughes G, et al: Facial paralysis of neoplastic origin; Diagnosis and management. Laryngoscope 90:1581-1595,1980.

2 .濱田昌史 ; 神経鞘腫 側頭骨内顔面神経鞘腫. JOHNS 20 (4) 553-557, 2004.

H15.7.17(初診時)

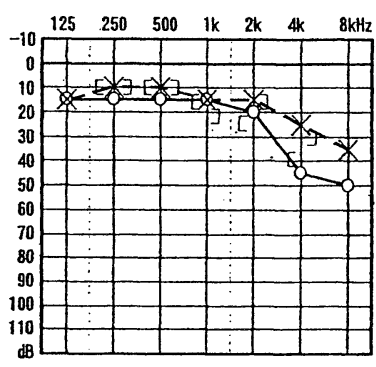

H16.6.4

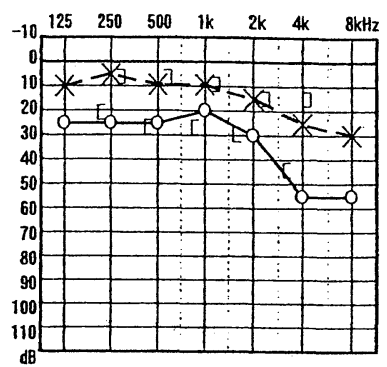

図1 聴力検査所見

\begin{tabular}{llcr}
\hline & & $H 15.11 .20$ & $H 16.6 .4$ \\
\hline \multirow{2}{*}{ ENoG } & 眼輪筋 & $68.1 \%$ & $58.0 \%$ \\
& 鼻筋 & $62.5 \%$ & $61.2 \%$ \\
& 口輪筋 & $94.4 \%$ & $91.0 \%$ \\
\hline 顔面神経麻瘏スコア & $34 / 40$ & $34 / 40$
\end{tabular}

\section{あぶみ骨筋反射 両側反応あり、左右差なし}

表 1 各種検查所見

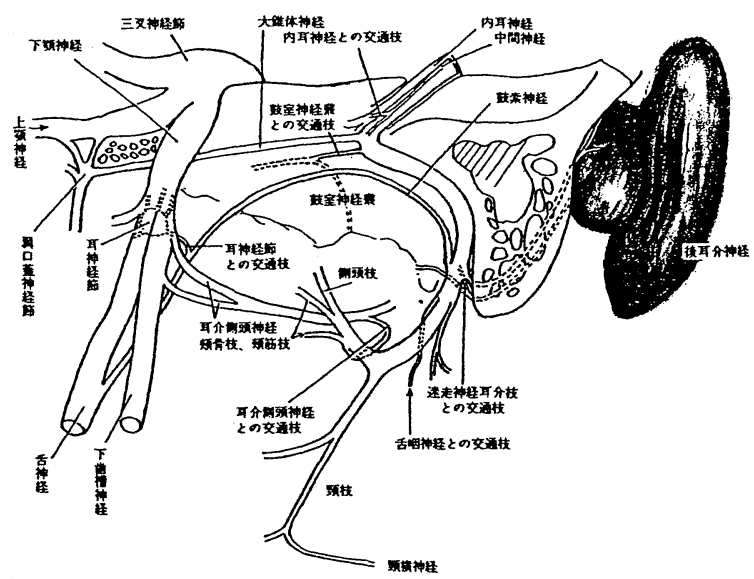

図 2 顔面神経走行図

（図説 解剖学 4 神経学 上條雍彦著 アナトーム社より引用） 